\title{
Paweł Teterycz
}

Klinika Nowotworów Tkanek Miękkich, Kości i Czerniaków, Centrum Onkologii

— Instytut im. Marii Skłodowskiej-Curie w Warszawie

\section{Przypadek 65-letniej chorej na czerniaka w stadium rozsiewu wieloogniskowego leczonej pembrolizumabem}

\author{
65-year old female with disseminated melanoma treated with pembrolizumab: \\ a case report
}

Adres do korespondencji:

Lek. Paweł Teterycz

Klinika Nowotworów Tkanek Miękkich,

Kości i Czerniaków, Centrum Onkologii

- Instytut im. Marii Skłodowskiej-Curie

ul. Roentgena 5, 02-781 Warszawa

e-mail: pteterycz@coi.pl

DOI: $10.5603 /$ OCP.2018.0059

Copyright $\odot 2018$ Via Medica

ISSN 2450-1646

\begin{abstract}
STRESZCZENIE
Niniejsze opracowanie przedstawia przypadek 65-letniej pacjentki, u której w 2013 roku zdiagnozowano czerniaka skóry w stadium zlokalizowanym. W lipcu 2016 roku stwierdzono następnie rozsiew choroby do płuc, brzucha oraz ośrodkowego układu nerwowego. Chora została zakwalifikowana do leczenia przeciwciałami anty-PD1 i w październiku 2016 roku otrzymała pierwszy wlew pembrolizumabu. W wyniku leczenia osiągnięto częściową remisję wszystkich opisywanych wcześniej zmian. Pacjentka w dalszym ciągu jest w trakcie leczenia. Niniejsza praca obrazuje aktywność pembrolizumabu w przypadku rozsiewu czerniaka do ośrodkowego układu nerwowego, niemniej jednak leczenie w takich przypadkach pozostaje wyzwaniem.

Słowa kluczowe: czerniak złośliwy, przerzuty do OUN, mutacja BRAF, przeciwciała
\end{abstract}

\begin{abstract}
This is a case report of a 65-year old female who was diagnosed with localized melanoma in 2013. Afterward, in July 2016, the spread of the disease to the lungs, abdomen and central nervous system was noted. The patient was qualified to anti-PD1 treatment and started on pembrolizumab in October 2016. She archived partial response in all of the lesions. The treatment is ongoing. This case highlights the activity of pembrolizumab in case of advanced, metastatic melanoma, yet the management of this disease with central nervous system involvement remains challenging
\end{abstract}

Key words: malignant melanoma, brain metastases, BRAF mutation, antibodies

\section{Wstęp}

Mimo znacznego rozwoju zarówno immunoterapii, jak i leczenia ukierunkowanego molekularnie opieka nad chorymi na czerniaka w stadium rozsiewu pozostaje dużym wyzwaniem dla lekarzy. Stwierdzenie to jest szczególnie prawdziwe w przypadku pacjentów, u których ogniska przerzutowe pojawiły się w ośrodkowym układzie nerwowym (OUN). Takie zmiany dotyczą 49-73\% chorych na czerniaka w IV stopniu zaawan- sowania oraz były historycznie związane z przeżyciem całkowitym sięgającym maksymalnie 4-6 miesięcy [1]. Wśród dostępnych obecnie w Polsce leków, w pierwszej linii leczenia systemowego należy rozważać zastosowanie przeciwciał skierowanych przeciwko receptorowi programowanej śmierci komórkowej 1 (PD-1) - pembrolizumabu i niwolumabu, lub w przypadku stwierdzenia obecności mutacji w kodonie 600 genu $B R A F$ inhibitory kinaz BRAF i MEK — dostępne kombinacje to dabrafenib $\mathrm{z}$ trametynibem oraz wemurafenib $\mathrm{z}$ ko- 
bimetynibem. Nadal w takiej sytuacji klinicznej nie jest dostępne leczenie za pomocą skojarzonej immunoterapii anty-PD-1 $\mathrm{z}$ anty-CTLA-4.

Przedstawiono przypadek 65-letniej pacjentki chorej na czerniaka w stadium wieloogniskowego rozsiewu do płuc, jamy brzusznej i OUN leczonej pembrolizumabem w monoterapii.

\section{Opis przypadku}

\section{Dotychczasowe leczenie i obciążenia}

Pacjentka po raz pierwszy zgłosiła się do poradni chirurgii onkologicznej w sierpniu 2013 roku zaniepokojona zmianą barwnikową na lewym ramieniu. Zmianę usunięto w znieczuleniu miejscowym, a w raporcie histopatologicznym rozpoznano czerniaka o typie guzkowym $\mathrm{z}$ naciekiem 1,9 mm według Breslowa, $\mathrm{z}$ owrzodzeniem oraz naciekami limfocytarymi typu non-brisk. Następnie we wrześniu 2013 roku chorej wykonano biopsję węzła wartowniczego (pobrano 2 węzły), wynik ujemny.

Pacjentka leczyła się długotrwale z powodu choroby Parkinsona (wymagała wszczepienia układu głębokiej stymulacji mózgu w listopadzie 2008 r.), przeszła również wszczepienie stymulatora serca DDD ze względu na blok przedsionkowo-komorowy II stopnia, który był związany z powtarzającymi się utratami przytomności. Pacjentka podawała też, iż była diagnozowana z powodu wola guzkowego tarczycy; przy rozpoczęciu leczenia znajdowała się jednak w stadium eutyreozy. Chora cierpiała również na organiczne zaburzenia nastroju.

\section{Rozsiew choroby i leczenie pembrolizumabem}

W lipcu 2016 roku pacjentka trafiła do szpitala rejonowego z powodu objawów ostrego brzucha. W trakcie operacji w warunkach ostrego dyżuru resekowano odcinek jelita cienkiego. W materiale pooperacyjnym rozpoznano rozsiew czerniaka. W wykonanym następnie badaniu metodą tomografii komputerowej (TK) stwierdzono ponadto obecność zmian przerzutowych w płucach, otrzewnej, węzłach chłonnych jamy brzusznej oraz pojedynczą zmianę ogniskową w lewej półkuli móżdżku (wymiary $16 \times 11 \mathrm{~mm}$ ). Opisano również obecność oponiaka w okolicy ciemieniowej prawej i złamanie trzonu kręgu Th7 w wyniku zmian osteoporotycznych. W oznaczeniu molekularnym nie stwierdzono natomiast obecności mutacji w kodonie V600 genu $B R A F$ w dostępnym materiale histopatologicznym. Pacjentka została zakwalifikowana do leczenia przeciwciałem anty-PD-1 i na początku października 2016 roku otrzymała 1 . wlew pembrolizumabu w dawce $2 \mathrm{mg} / \mathrm{kg}$ mc. podawanej co 3 tygodnie. Przy przyjęciu w celu podania 1. kursu leczenia w badaniach laboratoryjnych stwierdzano niedokrwistość (stężenie hemoglobiny wynosiło 10,2 g/dl), a aktywność dehydrogenazy mleczanowej (LDH, lactate dehydrogenase) przekraczała górną granicę normy (GGN). W grudniu 2016 roku pacjentka przeszła dodatkowo napromienianie stereotaktyczne na obszar zmiany przerzutowej w obrębie lewej półkuli móżdżku.

\section{Odpowiedź na leczenie}

Już w pierwszej, kontrolnej TK, którą wykonano w 12 tygodni po rozpoczęciu leczenia zaobserwowano zmniejszanie się zmian mierzalnych spełniających kryteria odpowiedzi częściowej według Response Evaluation Criteria In Solid Tumors (RECIST v. 1.1). W czerwcu 2017 roku w okolicy opisywanej poprzednio zmiany ogniskowej w móżdżku opisano jedynie „6 mm linijne wzmocnienie kontrastowe bez obrzęku". Natomiast w ostatnim badaniu obrazowym (sierpień 2018 r.) jedyną mierzalną zmianą był węzeł chłonny w zakresie jamy brzusznej o wymiarze do $13 \mathrm{~mm}$. Na rycinie 1 porównano wyniki badań obrazowych sprzed leczenia oraz ostatnich dostępnych.

\section{Działania niepożądane}

Mimo licznych obciążeń internistycznych chora dobrze znosiła leczenie. Najistotniejszym powikłaniem terapii były zaburzenia funkcji tarczycy - początkowo nadczynność (grudzień 2016 r.), a następie jej niedoczynność leczona substytucją lewotyreksyny (pacjentka kontynuuje leczenie do dzisiaj). Poza tym chora okresowo zgłaszała świąd skóry o małym nasileniu, ustępujący po zastosowaniu emolientów.

Zgodnie z nową Charakterystyką Produktu Leczniczego w sierpniu 2018 roku zmodyfikowano dawkę pembrolizumabu na $200 \mathrm{mg}$ na cykl (flat dose) [2]. Pacjentka nadal kontynuuje leczenie.

\section{Omówienie}

Zarówno podwyższona aktywność LDH, jak i obecność przerzutów czerniaka w OUN stanowią niekorzystne czynniki rokownicze. Dostępne dane potwierdzają jednak skuteczność przeciwciał anty-PD-1 w przypadku bezobjawowych zmian w OUN (w przypadku objawowych przerzutów należy prawdopodobnie rozważyć zastosowanie łącznie przeciwciała anty-PD-1 oraz anty-CTLA-4) [3]. Należy również zauważyć, iż w cytowanym badaniu lepsze wyniki kontroli wewnątrzczaszkowej oraz przeżycia całkowitego osiągnięto, gdy leczenie rozpoczynano od immunoterapii, a nie od inhibitorów 


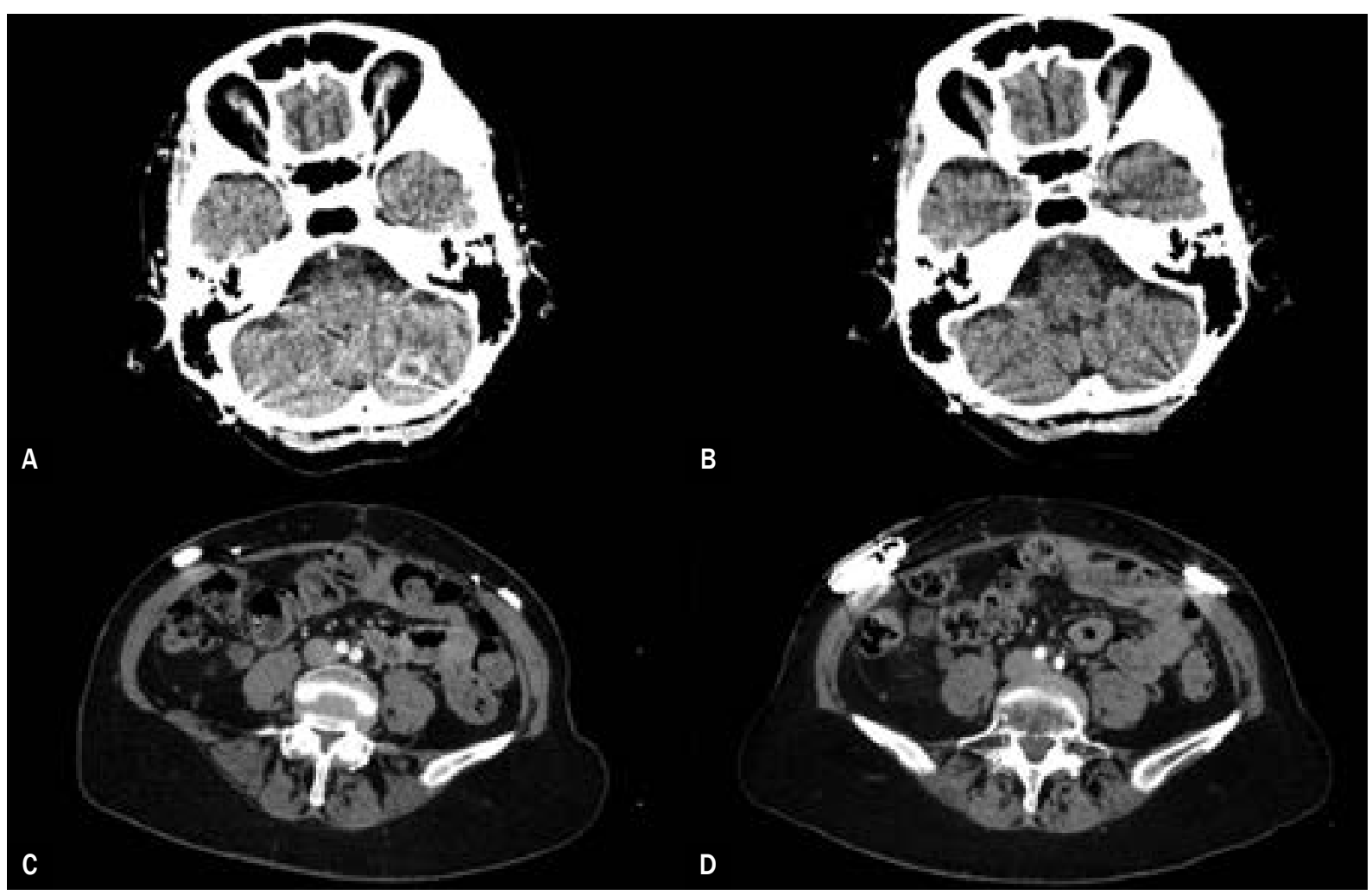

Rycina 1. Dynamika zmian przerzutowych u chorej. Zmiana w móżdżku na początku leczenia (A) oraz całkowita remisja w sierpniu 2018 roku (B). Zmiana w okolicy dolnego bieguna prawej nerki na początku leczenia (C) oraz w sierpniu 2018 roku (D)

BRAF/MEK. W dostępnym wyniku badania II fazy obejmującym grupę 18 pacjentów z rozsiewem czerniaka do OUN - pembrolizumab stosowany w monoterapii spowodował trwałą, obiektywną odpowiedź (zarówno wewnątrzczaszkową, jak i systemową) w $22 \%$ przypadków [4]. Istotnym elementem w postępowaniu terapeutycznym w takiej sytuacji klinicznej może być skojarzenie immunoterapii z radioterapią stereotaktyczną na obszar przerzutów do mózgowia, dzięki czemu możliwe jest uzyskanie efektu synergistycznego. Należy podkreślić, że opieka nad chorym na czerniaka z zajęciem OUN powinna być prowadzona $\mathrm{w}$ zespole wielospecjalistycznym oraz że u każdego takiego pacjenta należy ocenić możliwości leczenia miejscowego (chirurgia/radioterapia stereotaktyczna).

\section{Piśmiennictwo}

1. Fife K.M., Colman M.H., Stevens G.N. i wsp. Determinants of outcome in melanoma patients with cerebral metastases. J. Clin. Oncol. 2004; 22: $1293-1300$.

2. Charakterystyka Produktu Leczniczego Keytruda.

3. Long G.V. Atkinson V., Lo S. i wsp. Combination nivolumab and ipilimumab or nivolumab alone in melanoma brain metastases: a multicentre randomised phase 2 study. Lancet Oncol. 2018; 19: 672-681.

4. Goldberg S.B., Gettinger S.N., Mahajan A. i wsp. Pembrolizumab for patients with melanoma or non-small-cell lung cancer and untreated brain metastases: early analysis of a non-randomised, open-label, phase 2 trial. Lancet Oncol. 2016; 17: 976-983. 